\title{
AMERICAN MUNICIPAL SERVICES FROM THE STAND- POINT OF THE ENTREPRENEUR
}

\author{
By Chester Lloyd Jones, Рh.D.
}

Research Fellow in Political Science, University of Pennsylvania.

The people of the United States have been said to possess great confidence in machinery. This is a characteristic quite as much of our political as of our industrial life. An example of the latter fact is the popular attitude toward public service corporations. The average man reads of monopolized industries, with their manipulations of prices and arbitrary charges for equal services, and at once looks to a new set of political machinery to eliminate the evil. $\mathrm{He}$ concludes that public service corporations are monopolistic in character and that the only way to cure the abuses connected with them is to summarily abolish the order of things that made the abuses possible. When the local services are poorly managed he seizes upon accounts of the successful management of similar enterprises by public officials in distant countries and decides that the remedy is to adopt the same system at home. This attitude of mind is brought about by drawing too uncritical a contrast between what exists under widely different conditions in a foreign country and the actual management of the home services. The assumption is made that the same political machinery will work the same results at all times and in all places. Instead it should be realized that the time and place are ordinarily the elements immensely more important, and that these being in an ideal condition the method of management becomes a comparatively unimportant matter. Given perfect conditions, and the discussion of the superiority of public or private management of the public services becomes purely academic, but so long as perfect conditions do not exist there is an opportunity for an honest difference of opinion as to the relative advantages of the two methods.

In the minds of all the chief question in the management of the public services is how to secure the greatest efficiency. Putting aside, then, the purely academic question of whether public (37I) 
or private capital should manage public services, it becomes simply a problem of solving which of the two methods under the conditions surrounding the particular enterprise gives greater promise of securing good results. Too much stress cannot be placed upon the fact that in choosing between any systems of managing the public services the community in which they are placed is an inseparable element in the problem.

It is largely from this point of view that the public service corporation in the United States claims that its administration of the public services is superior to that by public officers. It is asserted that under present conditions private management brings better net results-the claim of greater efficiency. That the government has a right to regulate the action of public service corporations is no longer a subject of dispute in the law of the United States. The right of the state to go even to the length of appropriating the services to itself in return for just payment to the owners or lessees is unquestioned, but if such action is taken it should be dependent on the advantages to be gained and not on the basis of sentiment or prejudice.

From the standpoint of the entrepreneur public services may be divided into two classes, according to the degree of professional skill necessary to their management: First, there are those which, after the original construction is completed, require only ordinary manual labor and a fair degree of executive and clerical ability to keep them in efficient condition. Such until recently has been the character of the work of street cleaning in even our large cities. In the management of services of this character but little difference need exist between public and private operation. A fairly able manager at the head and a fair devotion to duty by the staff should produce passable results. At the other extreme stand those branches which demand a high degree of executive ability, good commercial judgment and a great technical skill to secure satisfactory results. Such are the gas and electric lighting plants and the transportation systems which have come to play so important a part in our municipal life. It is very evident that the majority of our public services approach the latter class much more than the former, and it is to the consideration of such enterprises that we will chiefly turn our attention.

The entrepreneur insists that under present conditions a system (372) 
of public management varies in success inversely as the complexity of the organization necessary to render the service. The chief points of superiority claimed for private management are as follows:

First, the effect of the desire of gain upon the management. It is all important to secure some force which will affect the entire administration with a desire for efficiency. Any element which fails to contribute to the sum of efficiency of the plant is a dead weight, a hindrance to the earnings of the company and lessens the quality of the service performed. The strongest stimulating influence which can be easily brought to bear upon the average man is the desire for gain. If this force can be enlisted on the side of efficiency the battle is won. There are many reasons why this is much easier of accomplishment under private management than under public officials.

The continual shifting of political parties and of the men in influence in the same party has prevented the development in our cities of a corps of municipal employees who can feel confident that faithful work brings permanence of tenure, and that greater ability insures more rapid advancement. The disintegrating effect of short terms and insecure tenure of office is evident in all ranks of the service, from the heads of departments to the day laborers. Since the tenure of office is but for a brief period and political fences are constantly in need of repair, there is every temptation on the part of the mayor and the heads of departments under him to use the means in their hands for their continuance in office. Manipulation of the municipal patronage can be practiced without causing important protest. Even if the public services suffer in no other way from this influence, their management is bound to be in more or less constant flux from changes of party or changes within a party.

The lower officers and laborers, too, feeling that in any case their term must be short, cannot but be susceptible to the thought that while the opportunity lasts the best must be made of it. $A$ temptation to make the most of an easy job at good pay is always present, and there is a strong possibility that the money interests of the municipality will have to suffer as a consequence. To say the least, the chance of advancement and permanent tenure being removed the feeling comes to the laborer that the position will last in any case as long as the term of office. The next election brings 
him an even chance of getting his work back again, but long and faithful service gives him no claim to preference. The security of his position depends rather upon his loyalty and services to the party than to the city's interests. His political activity becomes more important in his eyes than his industrial duties, and this attitude inevitably leads to a disposition to "sit down on his job."

Another disadvantage that the short term of office brings to the publicly-elected manager of the city services is that, no matter how anxious he may be to serve the municipality creditably, he hardly has time to become familiar with his duties when he is turned out of office. The branches of a large city service are so many and intricate that it would take almost a whole term for the new official to become truly acquainted with the department it was his duty to manage.

As a general rule the man elected has much less experience in management of work similar to that over which he is to preside than would a man chosen to manage a private business of the same size. Take, for example, the management of a big city gas plant or street car system. What guarantee have we that the popularly elected chief will have seen the service in the lower positions in a similar enterprise which would be required of one put in charge of a like concern privately managed? We are not here concerned with the question of whether or not the public can ever be impressed with the necessity of electing experienced men to manage their public services, but simply with the fact that the history of American municipal enterprises does not prove that they regularly do so, while the history of privately managed services shows the adoption of that practice.

The public officer has generally less technical training than the one selected under private management. The very circumstances of American municipal politics at the present time, where the salaries of the offices and the patronage connected with them constitute the chief legitimate reward for political service, make it highly improbable that the more important offices connected with the publicly-managed enterprises will be given to men who have not taken an active part in securing the success of the party in power. This so narrows the number of men specially fitted by education who are also apt to be selected for the offices by the political party as to practically eliminate the class entirely. Further, the really first- 
class man would not only be thus debarred, but as a rule would not accept the position if offered because of the better opportunities obtainable in the field of private enterprise. Under these conditions the public services must operate at a disadvantage. It means that as a rule the man who is at the head of the work is not a master of the technique of operation in his department. He must rely upon his subordinates for advice and information which he should himself be in a position to give. He cannot see so clearly what should be done, and adopt a firm and consistent policy to carry it out.

These are the disadvantages of public management when the heads of departments are chosen directly by the people. Appointment by their political representative, the mayor, or election by councils or by a combination of these methods, has much the same effect. A greater independence of selection may sometimes be obtained, but the controlling influence is more apt to be politics than efficiency. Even if the appointed officer wishes to maintain an independent attitude, to carry on the operations of his department on strictly business principles and to keep his selection of employees free from any but industrial considerations, he can hardly expect to carry out these plans. Councilmen will unfailingly urge upon him the employment of this man and that, regardless of whether additional help is needed or not. The temptation to create a position for such an applicant or to discharge some one not possessed of political support is great. The head of a department knows that his plans for keeping up a high standard of efficiency are first and last dependent upon receiving adequate appropriations from councils. To get out of sympathy with the representatives would be to antagonize the very body upon whom he must depend for his resources. $\mathrm{He}$ is thus placed between two fires-he must choose between allowing politics to enter into the management of his labor account or he must run the risk of creating hostility or at least lack of interest on the part of councils. As a rule the head of a department chooses what he considers the lesser of the two evils and surrenders his labor account to exploitation. The door once opened, it is almost impossible to check the advance of politics, and the would-be impartial director finds himself forced into the active campaign. This picture is not an exaggeration, as is proven by the experience of many cities. In practice we find that the appointive head, though he may often have the advantage of experi- 
ence over the officer directly elected works under no less a disadvantage than he. The management of the Philadelphia gas works illustrates the case. Though the chief was appointed and at first made a show of independence, his forced reliance on councils soon reduced the department of gas to a mere wheel in the machine.

Providing that the management of city services is under the charge of boards elected for so long a term as to constitute practically permanent bodies a greater independence of action may reasonably be expected from the members, but the appointments are still bound to be sought by and as a rule, given to the men who have rendered yeoman service to the party rather than to those who have the best experience and technical training. The limited possibilities in the way of salary remain the same as where the officers are elected. Even granting that the officers are well qualified when elected or appointed to the permanent board they have not the same incentive as when working for a personal employer. The loyalty to the municipality is not, with notable exceptions, as keen as the loyalty to the private employer. The officer is almost sure to hold his position for the full term even if no great efforts for improvement are made, and that fact-all unconsciously, perhaps, but none the less surelylessens his efficiency as compared to the man who realizes that his position and advancement depend upon his best efforts every day and his being up with the times in his plans for extension and improvement.

Even when the head offices are filled by the members of a permanent board there still may remain the management of the employment list on the spoils principle. This of course means that the larger portion of the service is left under the same disadvantages as before described. These, in brief, are the conditions which put the personnel of a publicly managed city service under a disadvantage as compared to private enterprise. In order to bring the two more sharply into contrast, let us review the similar points as shown in an average private corporation. Here, again, the comparison is not between what should be and what is but is based on present conditions in the United States.

Those at the head of the private company are responsible to the stockholders much more directly in fact, however it may be in theory, than are our public servants to the people. They have greater reason to believe that their offices are permanent during 
good behavior. Efficiency is the chief claim to permanence of position and exceptional ability is rewarded by rapid advancement. No time is wasted in non-industrial pursuits, such as caring for the party fortune in the employee's own ward.

Secondly. Experience and technical training are at a premium and are definitely sought after from first to last. The salaries are higher than in public enterprises where the officer's responsibility is the same.

Thirdly. There is continuity of policy. The company cannot be carried along on any but sound business principles. The consciousness of the permanence of the interests involved makes the directors less prone to adopt a policy which would temporarily bridge over a difficulty at the cost of increased expenditure later on. There is no temptation to conceal the state of affairs "until after election," as must often be the case where party interests clash with those of the public industries.

Besides the disadvantages connected with the personnel of management and operation there are other limitations of municipal administration. In the management of the finances of the public services the city is distinctly handicapped. The administration of any large corporation is subject to occasional demands for large amounts of money which cannot always be foreseen. Such are the unusual expenditures caused by accidents or the necessity of making an important addition to the plant at once. To meet such a condition is difficult for most of our cities. An emergency fund large enough to cover such demands would prove too easy a source of income to be placed in the hands of the ordinary authorities. Such a practice would soon lead to appropriations for "extraordinary" purposes which would come to be counted upon as a regular source of income for the department.

To make the appropriation rest on special action of councils also would be a possibility, but would not be entirely satisfactory. Councils are not always easily convinced of the advisability of an expenditure even when it would appear an imperative necessity to even the casual observer. Reluctance to incur the criticism through running up the tax rate or desire to spend the available money on some more brilliant but less necessary project has defeated many excelient and imperative improvements and extensions in publicly managed city services. Even if councils realize 
the advantage or need of certain changes it may be impossible for them to grant the money, though they wish to do so. Many of our cities also have already reached the statutory limit of indebtedness and it would be impossible for them to raise the money needed to meet any largely increased demands upon their treasuries. Thus the improvement, though it might be all important to have it made at once, would have to be postponed until the legislature could, by special act, allow the city to increase its indebtedness. Whatever method of solution is adopted it seems clear that the city is at a distinct disadvantage in meeting unusual demands which may be made upon it for maintaining its public services at their highest efficiency.

A private company in a similar position experiences no such hindrance. A good financial risk can easily secure immediate command of capital, and does not have to go before a local or state legislature where conflicting interests may delay if not defeat the needed appropriation. The financial interests of those managing the company also prompt them to be on a keener lookout for any unusual demand which may be made upon them. They hold a better chance of foreseeing the necessity for extensions, alterations or improvements, and have better facilities for meeting the situation when it comes.

Much of the writing denunciatory of private management of public services is based on the evil effects of the influence of corporations in politics. Many would be willing to concede the superior efficiency of private management in general, but insist that all the advantages gained through such administration are much overbalanced by the corrupt practices due to intrigues in the local legislative bodies. The evils connected with attempted franchise grabbing are so great it is asserted, that the only way to abolish these influences is to effectively take the services out of politics by putting them under public management absolutely. Such arguments are based on the assumption that political influences are removed by delivering the services into public control. Politics are to be removed by placing the management in the hands of politicians. Thus stated, it becomes clear that the adoption of control by the public does not necessarily mean all it seems to indicate. As a matter of fact, under present American conditions, politics are a permanent factor in the management of public services whether under 
private or public operation. The patronage wielded by public officers is no whit less an important factor in local politics than that exerted by the franchise-holding companies. Beyond a doubt such influence is baneful-and in the one case quite as much as in the other. Whether we shall be able to develop laws and a public opinion which will eliminate these influences is still a question for the future. Our course of action for the present must be planned with a frank recognition of the existence of such influence and the object of reducing it to a minimum. No one who considers the situation carefully would assert the presence of political influence in the one case and deny it in the other. The best interests of the community demand that whatever system of management be chosen that politics be eliminated. For the good of the corporations also it is beyond doubt to be desired that they should confine themselves wholly to industry. Under present conditions the temptation to enter politics for the defense of their interests is in many cases almost irresistible. Oftentimes these interests may be legitimate and need defense only due to the general prejudice against the management of businesses affected with a public interest by private individuals.

This state of affairs is most unfortunate both for the public and for the entrepreneur. On the one side it produces an acute distrust of all companies making proposals to do public work. Every proposition is attacked as if it were an attempt to legalize the stealing of public money. The representatives of the people are often prejudiced and unable to consider the purely industrial side of the enterprise in question. Instead of attempting to attract capital while fully protecting municipal interests, they are apt to approach the granting of a franchise in a hostile attitude, and often insist on useless stipulations which are an expense to the company and of no advantage to the community. As an example of such specifications may be cited the requirement made by one of our largest cities that service pipes for gas must be put in every sixteen feet. When it is remembered that such services often, as in this case, extend for long distances along parks and undeveloped districts the regulation appears ridiculous as well as useless.

The lack of sympathy between the public and its servants has an equally bad effect upon the attitude of the latter. Realizing that the spirit of many of those from whom they must get their rights is 
one of hostility and unreasoning prejudice, they assume the stand that unfair measures may be used to overcome unfair treatment. Once the field has been entered, there is the temptation to extend the company's activities beyond the defense of their legitimate interests to the securing of special and questionable privileges. The influence used to prevent prejudiced or "hold-up" legislation may easily be continued to deaden the convictions of would-be honest representatives. Examples of the use of corporate influence in this way fill all too many pages of the history of American municipal councils. The general result of such a state of affairs is mutual distrust and recrimination.

It must not be supposed, however, that by removing the public services from private management all evils connected with their administration will be at an end. Our American experience demonstrates quite the contrary. The only definite change which necessarily results is the transfer of the influence exerted by the private companies into the hands of the local politicians, an alternative by no means insuring improvement. It is not to be expected that in a country where the rewards of office are the most important object of political struggles, rather than any honor or social position attached thereto, that the large patronage offered by the payrolls of the publicly managed municipal services would not prove a prey to the ward politician. The chance to secure "jobs" with liberal pay at public expense for the political and personal friends of the successful candidates is too tempting to be resisted. It may, of course, be argued that an efficient civil service would put all the positions of this character out of the reach of the politicians. That is doubtless possible, but the creation of an effective civil service law for the management of the present public positions should be a prerequisite before the city should embark on new and expensive departures in municipal industries. When the cities show the willingness and the ability to create a truly efficient civil service the field may not be so difficult for public administration of the public services, but until such a move is not only advocated but carried out in good faith, any increase in the activities of a city only opens a longer payroll for exploitation by the "boss."

This fact is so patent in the history of American municipal industries that it is worth while to illustrate it from one of the most conspicuous examples-the notorious experience of Philadelphia in 
the management of her own gas works. Hardly a branch of this now famous experiment failed to show signs of exploitation for political ends.

The first account to be attacked was, of course, that promising the greatest number of positions to clamoring political dependents. This was the labor list in the manufacturing and distributing departments. High wages were paid-twenty-five per cent over the price for labor on the open market. The chief of the gas bureau was constantly besieged by the friends of various councilmen in search of easy work at high prices. The lists were padded with a number of laborers far beyond the actual needs of the plant. So many were there indeed that it is asserted that had all the employees been stood shoulder to shoulder, room could not be found for all of them at one time on the grounds of the plant. Naturally, under such conditions there was shirking of work on all sides, and some favored ones turned up at the works, it was said, only on pay day. The amount of work each had to do varied in accordance with the influence of his friends in councils. Receiving these easy jobs from the political boss, the employees were in turn exploited by him by means of semi-annual "voluntary contributions" to the party in power.

The purchasing and selling accounts were likewise abused. Coal was bought from favored firms only, the residual tar and ammonia always went to a single firm, though nominally sold to the highest bidder. In practice there was but the one bidder. When another bidder on one occasion put in a bid higher than that of the regular contractor the award was not given him "because he did not have the facilities for handling the product." The coke was disposed of through a member of select council. The charges entered uncler the blanket account of "miscellaneous" exceeded \$100,000 a year, and there were large amounts charged against such accounts as "ice," "matches" and "drugs and horse medicine."

The works were exploited indirectly also. Councils were anxious to cut down all appropriations for improvements and extensions in order to turn as large an amount as possible into the treasury as "profits of the works." This would enable them to keep down the general tax rate and have money for more favored plans, but it had a disastrous effect upon the general condition of the plant. Small and rotten mains and service pipes were left unrenewed, thus caus- 
ing a leakage in some years of as much as thirty per cent of the gas manufactured. Antiquated machinery was kept in use tiırough the refusal of councils to put in modern appliances-a practice which cost the city in wasteful methods of production far more than would have been the cost of new apparatus. Councils even went so far as to cut down very materially the use of the gas for public lighting. In the place of the public gas lamps light was bought at high prices from gasoline and electric lighting companies. These were private concerns in which councilmen and others prominent in local politics were interested.

In a word, the management of almost every branch of the public gas works was dictated by politics. Not only the heads of departments, but every employee from the top to the bottom of the labor account threw his whole influence into political affairs. The tenure of the party in power marked the tenure of office of the employees. Such was the experience of Philadelphia in the management of a municipal industry.

It is not contended that this is in all respects a typical case and that the same thing would occur in every detail in all our American cities did they undertake similar services. That such is not the case is proven by the experience of some of our cities in similar enterprises. But the example is given to show what has actually occurred in one of the most important experiments in municipal ownership in America. The circumstances of other American cities are not so different as to overthrow the presumption that the possibility of similar abuses exists there also, though not perhaps in the same degree as in the above instance. The example is given only to drive home the argument that under present conditions it is entirely possible for politics to play quite as large a part in the management of public services when under public as when under private control.

This being the actual state of affairs, the important question to be answered is: In which way can the connection of the public services and politics be more easily minimized. If public ownership is to be chosen radical measures must be adopted to remove all control of the municipal industries from possibility of political interference. To widely extend the functions of city government, thereby increasing the temptation to abuse of patronage, seems in itself to 
introduce an element making it increasingly difficult to keep a civil service system on a strictly non-partisan basis.

The other alternative is to elect representatives of such character as to command public confidence and who will be able to guard the city's interests in making arrangements with contracting companies. Each of these methods carries with it the possibility of honest management. On $t^{t}$ e point of integrity there would be little to choose between the two, carried on under ideal conditions. Improvement over present conditions must in either case come through raising the character of the representatives. A simple change from one set of machinery to the other will accomplish nothing.

The point then is: Is it easier to elect men who will be judges of a fair contract or men who will be able to run our municipal industries at a standard of efficiency equal to the average of private management. The former seems much more easy of attainment than the latter. The chances of our getting by popular vote a man with intelligence to determine the provisions of our contracts seem much greater than our chances of getting men specially suited by experience and education to carry on our municipal industries. The average man can choose work for the carpenter to do and judge the work when done much better than he can do the work himself. Similarly, the average representative can choose the terms upon which the city will have its work done and can judge whether it has been done according to the agreement much easier than he can carry out the plan himself. If the representatives of the people cannot be trusted to make fair terms with a contracting company how can they be trusted with the entire management of an industrial enterprise?

There is but one limit to the power of the public to regulate the conditions upon which they will give the public services into the hands of private companies-a fair return to capital. What is a fair return is, again, largely settled by the conditions offered in the contract. If the agreement is so strict as to make it impossible to raise the earnings of the company above the average of industrial undertakings in the community then it is clear that the city must hold itself ready to guarantee that the earnings shall reach that standard. Otherwise capital will of course refuse to take up the project. In case the municipality, on the other hand, does not care to assume the chance of loss by the company it must be prepared 
to grant a larger possible rate of return in exchange for its freedom from liability.

Within these limits the city may take all necessary measures to protect its interests in its public services. The more clearly the city evinces its desire to guard its own interests and at the same time to grant to the private company a reasonable rate of income and to protect it from unreasonable interference with that income, the less will be the desire and the temptation of the company to interfere with local political affairs.

Such an agreement would secure to the city all the advantages claimed by the advocates of municipal operation without the increased responsibility of direct management. A municipally-operated plant would in any case withdraw from other branches of industry the same amount of capital as would be employed in the enterprise by a private corporation. The interest on that capital must in the one case just as surely as in the other finally be paid by the community at large.

The choice between the two methods of operating the municipal services must depend not on what may be accomplished under ideal conditions, but upon the likelihood of efficiency under present conditions.

Under American conditions to-day, then, the entrepreneur would maintain that:

I. The direct responsibility present under private management makes it possible for a higher degree of efficiency to be obtained than under public operation.

2. The stimulus of gain can be made a more powerful element working for efficiency in all branches of operation under private than under public control.

3. The influence of politics upon the public services can be lessened more easily by having the representatives determine the terms upon which the city services shall be let out under contract than by turning the entire administration of the services over to the representatives.

4. By the granting of contracts clearly safeguarding both the interests of the city and the investor the management of the public services may be brought to the highest degree of simplicity, economy and efficiency. 